\title{
Between Sovereignty and Culture: Who is an Indigenous Intellectual in Colombia?*
}

\author{
JOANNE RAPPAPORT
}

Summary: Recent studies of Latin American indigenous intellectuals affiliated with social movements demonstrate that, while the hold that national intellectuals have as mediators between the state and civil society may be precarious, intellectuals from subordinated minorities are intermediaries between the national society and minority groups, successfully articulating ethnic strivings within national arenas and building ethnic discourses in local communities. But in order to comprehend the success of indigenous intellectuals, it is necessary to inquire into how their discourse is developed internally. To achieve this, we must pay close attention to the heterogeneity of the indigenous movement, in which an array of different types of intellectuals interact and debate issues in a range of ethnic organizations. This article explores the complexities of the negotiation of ethnic discourse by intellectuals within the Regional Indigenous Council of Cauca, a Colombian indigenous organization, focusing on a conflict in which indigenous cultural activists and politicians are at loggerheads over the nature of indigenous political autonomy.

\footnotetext{
* The research upon which this article is based was conducted from I995 to 2002 in Cauca, Colombia, thanks to the support of an international collaborative grant from the Wenner-Gren Foundation for Anthropological Research, as well as support from the Graduate School of Georgetown University. My research was conducted within an international collaborative team composed of Colombian academics (Myriam Amparo Espinosa and Tulio Rojas Curieux of the Universidad del Cauca); foreign scholars (David D. Gow of George Washington University, and myself); and indigenous intellectuals (Adonías Perdomo Dizú of the Resguardo Indígena de Pitayó and Susana Piñacué Achicué of the Consejo Regional Indígena del Cauca (CRIC)), who came together to engage in a dialogue focused on our distinct theoretical orientations, methodological approaches, and political commitments. I am indebted to the other members of the team for their acute insights into Caucan ethnic politics and their commentaries on my own work. I also entered into a close collaboration with members of the bilingual education program of CRIC, and owe a great debt to Graciela Bolaños, Abelardo Ramos, and Inocencio Ramos, for their astute observations and critiques, as well as for their immense hospitality. This article is drawn from a longer book manuscript, Intercultural Utopias, written while I held a National Endowment for the Humanities fellowship at the National Humanities Center during the 2002-2003 academic year. I thank Michiel Baud and Rosanne Rutten for their very helpful suggestions, which have made this article more persuasive.
} 


\section{INTELLECTUALS IN LATIN AMERICA}

Some observers assert that post-Cold-War Latin American intellectuals are in crisis, having lost their status as mediators between strong Latin American states and weak civil societies. In their traditional role as importers of ideas from abroad - what Brazilian literary critic Roberto Schwarz has called "misplaced ideas" - intellectuals have simultaneously stood in for international thinkers and for local constituencies. In so doing, argues Renato Ortiz, they reinterpret local and international ideas, creating national philosophies: "If intellectuals can be defined as symbolic mediators, it is because they fabricate a link between the particular and the universal, the singular and the global." ' Such globalizing factors as migration and the expansion of transnational markets on the one hand, and the rise of subordinated groups in rapidly decentralizing states on the other, have obviated the need for such "keepers of truth". However, Nicola Miller argues that, on the contrary, twentieth-century Latin American intellectuals were never effective mediators between civil society and the state because they were encompassed by the state through containment, cooptation, or suppression. She reasons, moreover, that their voices - whether in favor or in opposition - were muted by the antiintellectual policies of most Latin American states, which relegated them to the lower rungs of the bureaucracy; the implicit acceptance on the part of many intellectuals of the modernizing discourse of the state also contributed to their silencing. ${ }^{2}$

Recent studies of intellectuals affiliated with indigenous movements in Latin America indicate that the crisis of national intellectuals is not being experienced by those from subordinated minorities, whose objective is not to create a national consciousness, but to build social movements. ${ }^{3}$ Their numbers have increased exponentially in the past two decades as indigenous organizations have taken center-stage, not only in countries such as Bolivia, Ecuador, and Guatemala, with majority or near-majority

I. Jorge G. Castañeda, Utopia Unarmed: The Latin American Left after the Cold War (New York, 1993), p. I 82; Renato Ortiz, A moderna tradição brasileira: cultura brasileira e indústria cultural (São Paulo, 1998), p. I39; Roberto Schwarz, Misplaced Ideas: Essays on Brazilian Culture (London, I992); George Yúdice, "Intellectuals and Civil Society in Latin America", Annals of Scholarship, i I (1996), pp. I 57-174.

2. Nicola Miller, In the Shadow of the State: Intellectuals and the Quest for National Identity in Twentieth-Century Spanish America (London, 1999); Beatriz Sarlo, Scenes from Postmodern Life (Minneapolis, MN, 2002), pp. I42, I47-I48.

3. Diane M. Nelson, A Finger in the Wound: Body Politics in Quincentennial Guatemala (Berkeley, CA, 1999); Esteban Ticona Alejo, Organización y liderazgo aymara, 1979-1996 (La Paz, 2000); Kay B. Warren, Indigenous Movements and their Critics: Pan-Maya Activism in Guatemala (Princeton, NJ, 1998). I use the term "indigenous movement" to refer to the myriad local, regional, and national organizations of native peoples in Latin America whose objective is the defense of ethnic rights. 
native populations, but in nations like Colombia, where only 2 per cent of the population is indigenous, but where their influence increasingly pervades the national consciousness. In particular, indigenous organizations have posed concrete alternatives to the nineteenth-century notion of a homogeneous Latin American nation-state, opening a space through their organizing strategies and through civil disobedience in which ethnic pluralism could be imagined. It is the intellectuals of these organizations who are fashioning discourses and institutional structures through which indigenous people have begun to play a significant role in national life, through participation in the writing of new national constitutions, in the creation of legislation that enhances minority participation in political process, and in the development of ideologies that inject cultural difference into education, healthcare, and environmental planning. In other words, intellectuals attached to the indigenous movement have served a mediating function, but their positioning within emergent popular organizations and ethnic movements has enhanced their voice, rather than muting it. They are organic intellectuals in a Gramscian sense, nourishing the imaginings of emergent sectors.

As I will illustrate in this article, however, it would be a mistake to focus exclusively on indigenous intellectuals as individuals who lay claim to indigenous identity. First, the collective nature of indigenous identity, articulated both through community structures of authority and through indigenous organizations, ties being "indigenous" to collective aspirations. Second, as I will demonstrate, not all the intellectuals affiliated with the indigenous movement identify as indigenous, although they support and sustain indigenous organizations. Gramsci's theory of intellectuals provides a background to these related issues.

Gramsci rooted his interpretation of intellectuals in the historical contexts in which intellectual work of all sorts maintains the hegemony of certain social classes or fosters the emergence of new sectors. Gramsci's notion of the intellectual is not so much focused on individuals, as on the relationship between intellectuals or groups of intellectuals and the social sectors in whose name they speak. Gramsci distinguished between those whom he called traditional intellectuals, who work within existing hegemonic sectors in order to maintain them - teachers and priests are good examples - and organic intellectuals who nourish the imaginings of emergent groups. For Gramsci, the notion of organic was not confined exclusively to those intellectuals who emerge from a given class. Instead, he emphasized that what is at stake is the creation of relationships between members of a class and intellectuals from another social sector who have chosen to ally themselves with an emergent group in the course of a struggle for hegemony. In other words, the creation of intellectuals involves not only fostering their emergence within a particular class, but also the assimilation of traditional intellectuals into that group, thus 
transforming them into organic intellectuals. ${ }^{4}$ As I will demonstrate, Gramsci's typology, which is inclusive in the sense that it envisions the movement of intellectuals across groups, is fundamental to an understanding of the indigenous movement, where intellectuals of native backgrounds interact with intellectuals from the dominant society in organizations that are consciously pluralist, looking to forge alliances with other subordinated groups in the construction of a new notion of nationhood in which ethnic difference is a source of strength, not weakness.

\section{A HETEROGENEOUS MOVEMENT}

During the past eight years, I have been involved in a collaborative ethnographic relationship with a group of organic intellectuals in the southwestern province of Cauca, Colombia, specifically, activists affiliated with the bilingual education program of the Regional Indigenous Council of Cauca (CRIC), one of Colombia's most prominent indigenous organizations, which unites the Guambiano, Kokonuko, Nasa, Totoró, and Yanacona ethnic groups under a common cause.5 Many of these cultural activists come out of rural indigenous communities called resguardos, communal landholding corporations with title granted in the colonial period by the Spanish crown and governed by annually elected councils, or cabildos. Their activist aspirations have led them to the provincial capital of Popayán to pursue political and cultural activities in the organization's regional headquarters.

Many cultural activists are Nasas who come from areas characterized by subsistence farming and the use of indigenous languages, places like the resguardos of Caldono on the western slopes of the Central Cordillera, a few hours from Popayán, or from the isolated communities of Tierradentro, four hours of hard travel to the west. ${ }^{6}$ Correspondingly, they tend to

4. Antonio Gramsci, Selections from the Prison Notebooks (New York, I971). Anthropologist Kate Crehan provides a useful gloss on Gramsci's notion of the role of the intellectual, which I have used in this brief synthesis of his argument; Kate Crehan, Gramsci, Culture and Anthropology (Berkeley, CA, 2002), ch. 6.

5. There is a broad panoply of local, regional, and national indigenous organizations in Colombia, CRIC being one of the oldest of these, founded in I97I. These groups frequently espouse conflicting discourses and ideologies, recruit from rival ethnic groups, and are commonly at odds with one another, although in the course of mobilizations against the state, they come together in a single voice. See David D. Gow and Joanne Rappaport, "The Indigenous Public Voice: The Multiple Idioms of Modernity in Indigenous Cauca", in Kay B. Warren and Jean Jackson (eds), Indigenous Movements, Self-Representation, and the State in Latin America (Austin, TX, 2002), pp. 47-80.

6. Subsistence agriculture has always been supplemented by short-term labor migration by men during the coffee harvest, or by women, who work as domestic employees in neighboring cities and towns. However, in recent years these communities have entered the global economy 
define "indigenous" according to the cultural characteristics of their home communities, where the native language is Nasa Yuwe, where shamanism provides a widespread alternative to Western medicine, and where the majority of the population supports the cabildo. Having received the bulk of their training as apprentices within the indigenous organization, the task of these activists is to produce a discourse of cultural revitalization that reconstructs local culture-bearers as modern ethnic actors. The major focus of their work is the creation of an educational infrastructure in which such ideas can be operationalized. This dual task involves a combination of community organizing with ethnographic, educational, and linguistic research.

Culturalist intellectuals employ discourses that diverge significantly from those of indigenous politicians, who are much less apt to make recourse to cultural forms and are more motivated to cast their objectives in a universal political language that is comprehensible to their allies in other social movements and to the state officials with whom they negotiate. CRIC's most forceful political leadership springs from northern Cauca, where in the early and mid-twentieth century, Nasas migrating from insular areas like Tierradentro sought employment on cattle ranches and in sugar plantations, and where Nasa lifeways have taken on the cadences of urban Colombian culture, given their proximity to the metropolis of Cali and the small city of Santander de Quilichao. While many of these leaders maintain a strong indigenous identity, they have opted for a regional organizational culture and discourse, as opposed to local ones. Thus, many of these men - for their ranks are largely male - are highly pragmatic social actors who pay little attention to the culturalist discourse of their colleagues. In fact, CRIC's cultural activists see themselves as the cultural conscience of the movement, and are constantly seeking to instill in the political leadership a deeper appreciation of the nuances of cultural difference. It is important to note, however, that cultural activists, like indigenous politicians, are intensely political, wedded to organizational strategies and CRIC's program of land claims, defense of the resguardo system, and support for cabildos. What is different about the two groups is the discourse that each employs to achieve these common objectives and the political space in which each moves.

Given their objectives, indigenous activists - whether cultural workers or politicians - are only intellectuals to the extent that they remain conscious of their ethnic identity, because this is what distinguishes them from those members of native communities who have acquired university

through the cultivation of coca and opium poppies. The Nasa have a long history of struggle against their Spanish and Colombian overlords, and thus brought to the indigenous movement a legacy of grass-roots organizing. There is, moreover, a critical mass of speakers of Nasa Yuwe, which has resulted in a Nasa leadership in cultural affairs in the Caucan movement. 


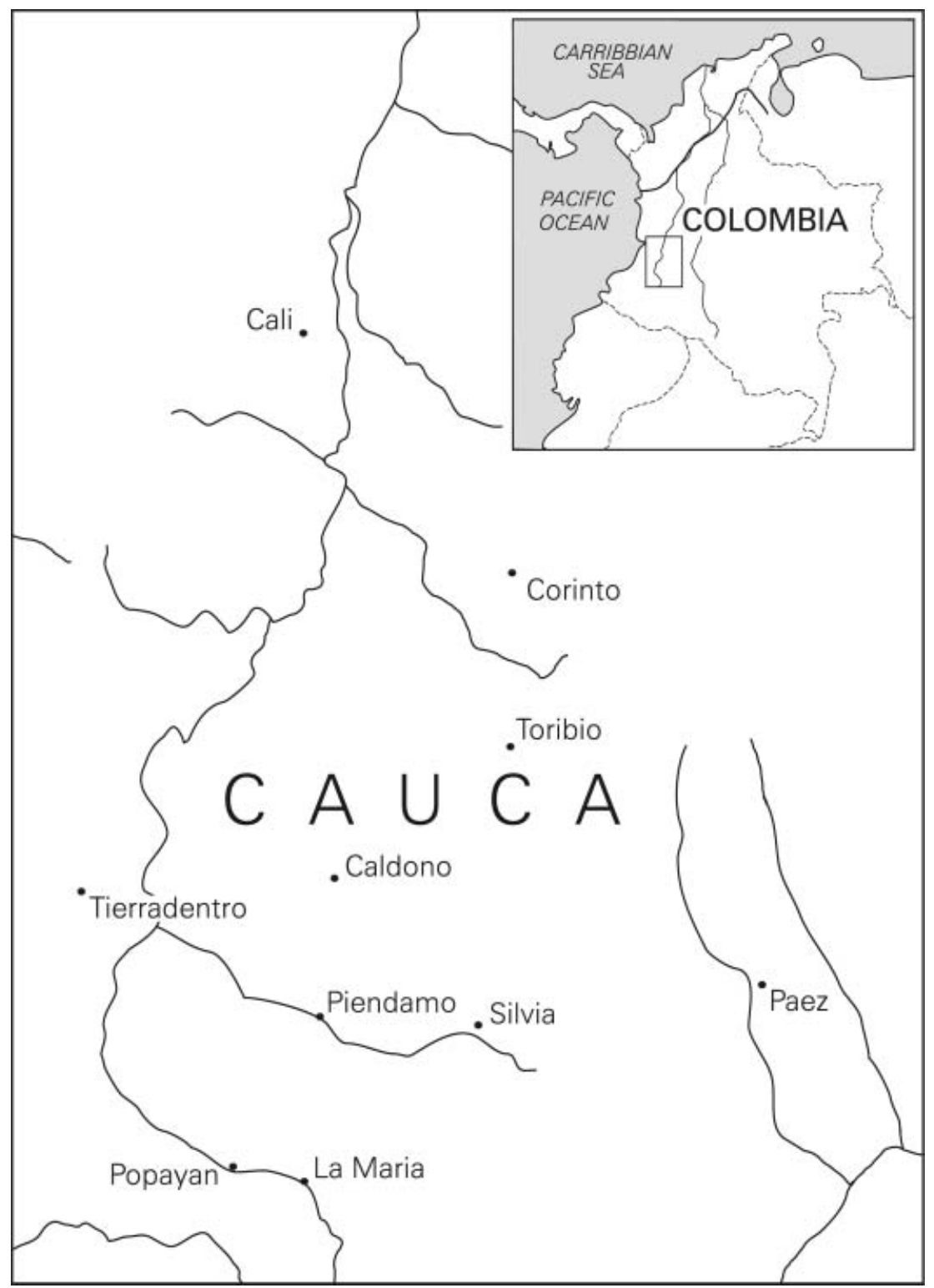

Figure I. Department of Cauca, Colombia. 
degrees and become professionals at large in the dominant society. ${ }^{7}$ That is, these activists see being indigenous as what makes their intellectual work meaningful, in contrast to other intellectuals, whose personal identities are not at the center of their role as intellectuals. In addition, it is through their identity as members of a collectivity that they function as intellectuals; their intellectual roles are articulated through participation in cabildos, in CRIC, or in related organizational settings, and not simply by virtue of their research and writing activities. The objectives of the organic intellectuals of CRIC thus revolve around their identity as native peoples and their service to the movement; their work is not harnessed towards the creation of academic knowledge, but to promote local activism infused by a contestatory indigenous ideology. Culturalist intellectuals achieve this by encouraging local schools to function as organizing venues and as incubators in which cultural forms can be revitalized. CRIC schools function as a base from which an ethnic ideology that originates from below can be articulated in dialogue with regional cadres. CRIC politicians - who are also organic intellectuals, but are more active in policymaking than in research and grassroots organizing - harness this discourse in their overtures to unorganized indigenous sectors and allies in other social movements, in their conversations with sympathizers, and in their negotiations with the state.

True to their calling as cadres who emerged from the native sector, indigenous public intellectuals in Cauca are generally loathe to call themselves by such an elitist epithet. Lacking the traditional status and tools of trade of those deemed by the dominant society to be intellectuals, they prefer to see themselves as activists who are engaged in intellectual concerns. That is, they consciously dissociate themselves from those who identify as intellectuals in Colombia. ${ }^{8}$ Likewise, the ways in which they conceptualize their cultural calling defy elite images of how indigenous culture functions. For many external observers, the cultural constructs that

7. For the latter, indigenous identity is not a necessary part of their intellectual endeavor, but instead, is frequently a hindrance to professional advancement.

8. However, indigenous intellectuals increasingly interact in academic venues with scholarly researchers. They are students in undergraduate and graduate courses, they present papers at scholarly meetings, and they circulate their observations through publications aimed at both an academic and a non-academic reading public. See, for example, Abelino Dagua Hurtado, Misael Aranda, and Luis Guillermo Vasco, Guambianos: hijos del aroiris y del agua (Bogotá, 1998); Bárbara Muelas Hurtado, "Relación espacio-tiempo en el pensamiento guambiano", Proyecciones Lingüísticas, r:I(1995), pp. 31-40; Rocío Nieves Oviedo and Abelardo Ramos Pacho, "Expresión del espacio en nasa yuwe", Lenguas aborígenes de Colombia: Memorias 2 (II Congreso de CCELA) (Bogotá, I992), pp. I75-183; Marcos Yule, Nasa üus yabt'n u'bun'i/“Por los senderos de la memoria y el sentimiento Paez": nasa yuwete twehn'i/"tradicion oral Nasa (Paez)" (Toribío: Programa de Educación Bilingüe Intercultural/PEBIN/Proyecto Nasa Toribío, I996). CRIC also publishes a broad range of books, pamphlets, and magazines, which circulate among bilingual teachers, as well as in pedagogical circles in Colombia and in the NGO community throughout Latin America. 
emerge from the indigenous movement are essentialist, in the sense that they appear to project coherent, unchanging, and primordial models of native uses and customs. Or they are "strategically essentialist," harnessing primordial sentiments to counter charges of inauthenticity by the powers that be. ${ }^{9}$ But, to the contrary, culture, as it is conceived by the indigenous sector, is dynamic and highly permeable. Indigenous intellectuals endeavor to create ethnic imaginaries out of utopian strivings that do not represent native uses and customs as they are lived, but project their revitalization in the future.

\section{COLABORADORES}

However, we cannot view indigenous intellectuals as self-sufficient. As we examine indigenous public intellectuals and their role in social protest, we commonly lose sight of the fact that they do not work alone, but in association with intellectuals from the dominant culture who have abandoned the task of the national intellectual who mediates in favor of the hegemonic state, to contribute to social movements that they feel will transform national society. The fact that CRIC is part of an indigenous movement does not mean that all of its militants are members of native ethnic groups. To the contrary, the day-to-day work of the organization is carried out by intercultural teams that include not only Nasas, Guambianos, and members of other indigenous groups, but also leftist intellectuals from urban centers - whom I shall call colaboradores, as they call themselves - who have dedicated themselves to indigenous politics and who bring much-needed skills to the movement.

Among the ranks of the colaboradores are university professors, who work closely with native activists and whose intellectual priorities have merged with those of their indigenous colleagues, resulting in a relationship that has shifted the paradigms used in the academy. But the relationship of these metropolitan intellectuals to the indigenous movement is uneasy, since they are outsiders to indigenous communities and to the political discipline of the indigenous organization. ${ }^{10}$ Furthermore, the

9. Gayatri Chakravorty Spivak and Elizabeth Grosz, "Criticism, Feminism, and the Institution", in Sarah Harasym (ed.), The Post-Colonial Critic: Interviews, Strategies, Dialogues (London, I990), pp. I-16.

I0. Diane Nelson, in A Finger in the Wound, and Kay Warren, in Indigenous Movements and their Critics, describe an almost adversarial relationship between Guatemalan urban intellectuals and the indigenous movement, and point out that few non-Maya intellectuals support Maya cultural aspirations. The Colombian case is considerably more fluid than the Guatemalan one. Many non-indigenous intellectuals in Colombia are highly supportive of indigenous organizations and have routinely worked as their allies. This does not mean, however, that external supporters are fully trusted by indigenous activists who, like other minorities, are wary of members of the dominant group, however supportive they may seem. Hence, the uneasiness between them. 
theoretical discourses that they employ, while frequently of interest to indigenous intellectuals, emerge from and are most pertinent to academic agendas, and are geared not toward promoting activism, but with an eye to producing academic writing; this makes this sector essentially untrustworthy - almost cannibalistic - for indigenous activists. Academics are traditional intellectuals who are not organic to indigenous organizations, but are sympathetic to them; they could almost be said to be in transition between traditional and organic status, given that, in the Gramscian model, traditional intellectuals could be potentially absorbed within the cadre of organic intellectuals.

More active interlocutors are the colaboradores who work full-time for ethnic organizations, whose everyday lives transpire in an indigenous milieu, and who submit to the risks and the discipline of ethnic organizations; colaboradores are, essentially, intellectuals from the dominant culture who are organic to the indigenous movement. Many of the most prominent members of this group function as interlocutors who stimulate discussion within the organization, but they rarely, if ever, publish their ideas in formats other than internal documents and reports. This sector is almost totally ignored in the literature, perhaps because colaboradores do not fit neatly within the essentialist models that we have created for analyzing indigenous organizations.

Despite the adherence of colaboradores to movement objectives, their discourses only partially mirror those of indigenous intellectuals, for the conceptual models that they employ originate in part in the worlds from which they have come, just as do those of academic interlocutors. In fact, their origins outside of the communities and their use of external ideas mark their ambivalent membership within the movement as "outsiders within". "I But, in spite of their close association with indigenous intellectuals, they are not, in any sense of the word, a vanguard of the sort that intellectuals in leftist parties hoped to constitute. Colaboradores see themselves as adherents to an existing movement, playing an equal and increasingly, a subaltern - role to the cabildos and the indigenous activists that form the backbone of the organization. If necessary, colaboradores can find a home outside the indigenous movement; while for the most committed, it would be painful to disengage from the indigenous movement, there are many other organizing venues in which they can incorporate themselves and further their political agendas, unlike the indigenous intellectuals who recognize that their very survival as indigenous people is what is at stake in the movement.

Gramsci's theory of intellectuals is useful in making sense of the internal role of colaboradores in indigenous organizations. In fact, if we are to take 
Gramsci to heart, we cannot study the indigenous movement without paying attention to the role of outsiders within, because they have achieved organic status alongside indigenous intellectuals. But, notwithstanding the utility of Gramscian thought for making sense of the relationship between indigenous intellectuals and colaborador outsiders, Gramsci does not supply us with sufficient conceptual tools to contend with the internal complexities of intellectual work in Cauca, nor, I suspect, in other locations.

The category of the organic intellectual provides a key to comprehending the interactions of the organization with external actors, but does not shed light on negotiations internal to the regional organization, or between CRIC and the local sphere of action, where a multiplicity of indigenous organic intellectuals operate, frequently at loggerheads with one another. There are considerable differences in the discourses employed by the cultural activists of CRIC's regional office and affiliated teachers or cabildo members working in local venues: while the former look toward leftist theorists, particularly those writing about bilingual education or grassroots development, to stimulate their construction of indigenous proposals, the latter are more concerned with fostering an exchange with other indigenous groups and with other subordinated minorities (such as Afro-Colombians) in the peasant sector. It is within the dynamic that unfolds between regional and local indigenous intellectuals, and among the different sorts of intellectuals who operate in these spaces, that ethnic projects are constituted, not in the imposition of one sector on top of another.

\section{COSMOVISION}

There is another significant group of local intellectuals: shamans - in Nasa Yuwe they are called thê walas - whose discourses are rooted in an exchange with the spirit world, and whose knowledge provides a potent language for the politicized construction of cultural forms. I call these individuals sabedores or "knowers", in acknowledgment of the recognition that the movement has given them as the source of the organization's cultural imaginings and their role as brakes against what the movement perceives as its ideological colonization by external forces. Unlike most activists, who choose to function as intellectuals - even if they do not accept to be labelled as such - thê' walas are chosen against their own wishes. After a lengthy period of illness and persistent visions, they come to the realization that they hold powers which, if not harnessed through ritual, threaten to engulf them. Shamans are very much more attuned to oral tradition and sacred geography than are other indigenous intellectuals and thus have a great deal more to bring to the table. Many cultural activists, in contrast, know little more about things spiritual than what 
they have read in movement publications or heard in workshops, that is, their knowledge is second-hand. While both groups employ an intuitive methodology that combines culturally self-conscious reflection with the collection of empirical information, the intuitions of the the' walas are grounded in empirical knowledge they acquire through the interpretation of bodily signs - vibrations and pulses that they feel in their extremities which non-shamans cannot fully comprehend and no-one can fully verbalize.

It is through the reappropriation of shamanic knowledge, called "cosmovision" by indigenous militants, that cultural activists hope to derive a new indigenous political strategy. Shamanic learning functions as a source of historical models and conceptual structures capable of transforming the priorities and objectives of the organization. The rituals that shamans conduct maintain harmony and balance in the universe, knowledge of which orients the development of the indigenous jurisprudence and legal procedures that are currently under construction, as Colombian indigenous people adapt customary law to the needs of their changing communities. The very notion of harmony embodied in ritual provides, in the opinion of culturalist intellectuals, a new model for behavior within the organization, a non-Western code of conduct. The oral narratives and origin stories with which shamans are intimately familiar provide the movement with a historical basis for asserting their difference. In fact, many of the key narratives in the oral tradition recall the efforts of colonial hereditary chiefs to establish resguardos - communally-controlled indigenous territories - and entreat cabildos and the regional organization to defend them as bastions of indigenous autonomy.

But there is another, more utopian facet of the cosmovision project. The wealth of shamanic lore must ultimately be converted into re-authenticated indigenous lifeways - ritual made familiar by repetition, house gardens tilled by local hands, healing practices replacing Western medicine - so that local people begin to live their cultural difference in their everyday lives, making the personal political, to appropriate a slogan from the I960s. For this reason, it is highly significant that CRIC linguist Susana Piñacué translates cosmovision into Nasa Yuwe as fxi'zenxi - vivencia or everyday experience. ${ }^{\mathrm{I}}{ }^{2}$ The hope is to reintroduce into indigenous communities lifeways that slowly become habitual, unremarkable, unselfconscious, in short, authentic.

Whether they are entirely successful in this goal depends to a great extent upon the indigenous community in which cosmovision is introduced, however. People from Tierradentro, where shamanic practice is

I2. Susana Piñacué Achicué, "Liderazgo, poder y cultura de la mujer nasa (páez)", in Joanne Rappaport (ed.), Retornando la mirada: una investigacion colaborativa interetnica sobre el Canca a la entrada del milenio (Popayán, forthcoming). 
accepted as an alternative to Western medicine and where shamans have always been active in cabildos, are more receptive to the discourse of cosmovision than are the Nasa of northern Cauca, who are closely integrated into the regional mestizo culture. Tierradentro shamans have been engaged for a number of years in collective research into cosmovision and played an important role in maintaining community cohesion after a I 994 earthquake that forced many villagers to resettle in distant locations. Correspondingly, there has been a recent burst of attempts to incorporate shamans even further into daily activities and political organizing in Tierradentro. In other regions, however, where shamans have not traditionally played a role in everyday life, cosmovision is far from becoming a vivencia, although it is a popular discourse among local teachers and catechists. In short, the cosmovision project is still a utopia, but one that cultural activists see as feasible and necessary.

\section{CONFLICTING DISCOURSES}

The remainder of this article will explore how negotiations among intellectuals organic to the indigenous movement take place on the ground, because it is only through such case studies that we can make sense of how multiplicity ultimately results in a persuasive organizational discourse. I will examine a recent confrontation in which tensions between various groups of indigenous intellectuals came to a head, a scenario in which the negotiation by intellectuals of a movement discourse is most readily apparent.

For the past three years the provincial administration of Cauca has been led by a Guambiano activist, Governor Floro Alberto Tunubalá. His election to the governorship of Cauca was made possible by the emergence of an alternative public sphere that grew out of a coalition of urban and rural social movements, with the indigenous movement at its vanguard. ${ }^{13}$ His administration reflects the diversity of the electoral coalition, bringing together in common cause indigenous activists, urban intellectuals, unionists, and peasant leaders. But what happens when cabildo members - who are prominent members of this contestatory public sphere - come into conflict with an indigenous-led state? For the next few pages, I will explore the antagonisms that flared when a group of community leaders attempted to impose what they called derecho mayor - their "greater

I3. On the notion of the alternative public sphere, see Nancy Fraser, Justice Interruptus: Critical Reflections on the "Postsocialist" Condition (New York, 1997), ch. 3. Unfortunately, the coalition was not strong enough in the 2003 gubernatorial elections to prevail against the traditional Liberal Party candidate, who won the election, but has since been barred from assuming office for irregularities in payment of contracts when he occupied another post. The National Electoral Council has ruled that new elections must take place (El Tiempo, 23 December 2003, "Cauca, sin gobernador"). 
right" as the original Americans - over the national law that the Tunubalá administration was bound by oath to uphold. This dispute, which erupted in the summer of 2002, magnifies the heterogeneity of the indigenous movement and brings into focus the complex and intertwined relationships of local and regional activists, colaboradores, and indigenous state representatives. As I will illustrate, this was a encounter between the culturalist vision of indigenous intellectuals and the discourse of sovereignty of native politicians, but with a telling twist: it is almost impossible to separate out the threads of who is a politician, who is a cultural worker, who is affiliated with a regional apparatus, who is a local, who speaks in the cadences of sovereignty, who can legitimately speak of cosmovision, and who is an intellectual.

Taita Floro Tunubalá - as most indigenous Caucans call him, using a Guambiano term of respect - is in his late forties. A model of the new brand of indigenous leadership, he has partially completed a university degree and has spent a great deal of time outside Cauca, serving as a national senator and as a development consultant. ${ }^{14}$ But Taita Floro also enjoys local legitimacy, having been elected to two terms as governor of the resguardo of Guambía, which is affiliated with the Indigenous Authorities of Colombia (AICO), an organization that operates parallel to CRIC and in Cauca, is largely confined to Guambianos. Indeed, Taita Floro's affiliation with Guambía defies any easy distinction between local and regional actors, given that the resguardo of Guambía controls this regional organization, which has its own political line in comparison to other Caucan ethnic groups, which are aligned with CRIC. ${ }^{\text {Is }}$ When in the public eye, Taita Floro's "Guambianoness" is accentuated, much to the consternation of the provincial elite: he wears the trademark blue kilt, black poncho, and fedora hat of his ethnic compatriots. He is equally fluent in Spanish and in Guambiano, although he speaks Spanish with a distinct Guambiano accent.

Taita Floro entered the governor's palace in Popayán with the support of AICO and CRIC, who came together in an unprecedented alliance in the wake of a series of occupations of the Pan-American Highway at a site

I4. The 199I Colombian constitution provides two senate seats for indigenous people, who run under the rubric of various indigenous organizations and political parties, but are chosen by the electorate at large. Taita Floro was one of the earliest indigenous leaders to hold such office.

I 5 . AICO espouses a grass-roots organizing model based on cabildos and does not have a central committee. There are no colaboradores inside AICO, although there have been outsiders working in solidarity with the organization, positioned on the outside (they are called solidarios). Historically, AICO supported the reincorporation of reclaimed lands within the resguardo structure, while CRIC did not always follow this model; this difference, which was fundamental in the late-I 970s, is no longer at issue. On the ideology of AICO, see María Teresa Findji, "From Resistance to Social Movement: The Indigenous Authorities Movement in Colombia”, in Arturo Escobar and Sonia Alvarez (eds), The Making of Social Movements in Latin America: Identity, Strategy, and Democracy (Boulder, CO, 1992), pp. I I2-133. 
called La María to protest the lack of basic services to indigenous communities, a coalition that that gave rise to his campaign. But his largest voting base was among non-indigenous urban dwellers who had tired of the stranglehold that the two mainstream political parties had on Caucan politics. Taita Floro has made his mark on Cauca. His efforts at organizing the governors of surrounding provinces in opposition to the US-inspired fumigation policies of Plan Colombia, and his encouragement of the manual erradication of ilicit crops attest to his broader political commitment beyond the boundaries of indigenous territories, as does the general development plan drafted by his administration, which promotes community organizing in nonindigenous areas and in the cities, in the hopes of dynamizing the mestizo and Afro-Colombian populations; one of Taita Floro's central concerns has been the paucity of participation in these sectors, evidenced in the high proportion of community development proposals his administration received from indigenous communities, which far surpassed the relative weight of the native population in Cauca. Taita Floro appropriates methods from his indigenous constituency, such as community assemblies and the notion of the minga or Andean communal work party, as tools to revitalize the public sphere in nonnative rural and urban areas.

While Taita Floro is the child of the indigenous movement, he is also the governor of Cauca, serving a much broader constituency than the roughly 30 per cent of the provincial population that identifies itself as indigenous. Hence, he feels a pull between two conflicting allegiances and sets of administrative priorities. Furthermore, as governor, he is subject to the restrictions of the Colombian state and he cannot make decisions that contravene its rules and regulations. Taita Floro regularly experiences, in the flesh, the tensions between leading an indigenous community and representing the state. In June and July 2002, one such contradiction emerged, when the indigenous authorities of the municipality of Caldono blocked the Pan-American Highway at La María, demanding that Taita Floro dismiss their municipal mayor.

\section{CONFLICT IN CALDONO}

Caldono is a large municipality encompassing six Nasa resguardos. Located to the north of the provincial capital of Popayán, Caldono is part of what indigenous activists call the "inside", those insular spaces in which contact between indigenous people and the national society are limited. Activists see these places as more culturally authentic and as embodying a set of lifeways that should be emulated by the indigenous organization through cultural planning and a heightened attention to ritual activity. ${ }^{16}$ Several of

I6. While it is the place of activists to promote the "inside", they expressed to me the feeling that 
the municipality's resguardos were home to intense land struggles in the early years of CRIC, when communities occupied haciendas lying within resguardo boundaries and incorporated them into their communal land base. In the course of this struggle, experimental schools were founded as organizing venues in which leaders could harness popular political sentiment for building CRIC from the grassroots up. These resguardos retain a vivid memory of Juan Tama, the mythico-historical hereditary chief of the Nasa, who left them a resguardo title that dates to the early eighteenth century and provides the narrative upon which contemporary oral tradition is based. This colonial document unites the various communities of Caldono into a single historical unit. ${ }^{17}$ In recent years, CRIC regional activists returned to Caldono to run for office in their respective cabildos, bringing with them a militant culturalist position that they had developed in the course of their work in bilingual education and a renewed interest in regional consolidation, using Juan Tama as a model.

Caldono's municipal seat was designated a zona de población under Law 89 of 1890 , the law that, until the I99 I constitution, defined the organization of the resguardo system and its nature as a vehicle for the assimilation of native peoples into the dominant society. The zona de población, as decreed in Law 89, was an urban district established in the midst of communal indigenous territory, home to a mestizo settler population that was not subject to resguardo jurisdiction. Such settlements were meant to diffuse national culture within the indigenous hinterland and to form the core of potential mestizo localities. As a result of this historical circumstance, the town of Caldono is still largely mestizo in character and there is considerable hostility between the urban center and resguardos. There are also various satellite towns with mestizo peasant populations and considerable Guambiano settlement throughout the municipality, making this an ethnically heterogeneous region. Until the Indigenous Social Alliance (ASI), an indigenous political party, successfully ran Nasa candidates in municipal elections in the I990s, the mayor was a mestizo, running a tight and ethnically segregated bureaucracy characterized by clientilistic political practices. ${ }^{18}$

intellectuals live on a cultural "frontier" from which they make forays "inside" and "outside", thus mediating the two constituencies; see Joanne Rappaport, "Los nasa de frontera y la política de la identidad en el Cauca Indígena", in idem (ed.), Retornando la mirada.

17. Juan Tama's title, written in 1700 but brought into the Colombian notarial record in I88I, can be found in the Archivo Central del Cauca, Popayán, "Título de las parcialidades de Pitayo, Quichaya, Caldono, Pueblo Nuevo y Jambalo", partida 843. On the importance of Juan Tama to colonial Nasa political aspirations and his continued prominence in contemporary oral tradition, see Joanne Rappaport, The Politics of Memory: Native Historical Interpretation in the Colombian Andes (Durham, 1998).

I8. José María Rojas, La bipolaridad del poder local: Caldono en el Canca indígena (Cali, 1993). 
But in 2000, ASI lost out to a mestizo politician, Gerardo Iván Sandoval, whom the cabildos accused shortly thereafter of having usurped lands destined for purchase by the resguardo of La Laguna. They also charged him with misuse of municipal funds and of supporting an upstart resguardo in the locality of Plan de Zúñiga, which the other communities refused to recognize. Beginning in late May, 2002, the cabildos sought Sandoval's resignation on the grounds that he was "unfit to govern them". They convoked a "permanent assembly", a state of belligerency marked by constant public meetings, enlisting CRIC's executive committee to assist them in persuading Taita Floro to remove the mayor from office. ${ }^{19}$

On 26 June 2002, the cabildos occupied the Pan-American Highway at La María, commanding their indigenous compatriots to join them in the struggle. Many cabildos from across Cauca half-heartedly sent representatives. La María was the site of a tent city, fed by a huge communal kitchen and patrolled by an indigenous civic guard armed only with staffs and made up largely of teenagers, young adults, and elderly women. Hundreds congregated $\mathrm{n}$ the large public space overlooking the highway, listening to the addresses of council representatives. Below, the road was blocked off by the civic guard and by hundreds of parked trucks, with Colombian soldiers lining the route. Before being allowed into the meeting space, visitors were subject to frisking by the guard and their identity papers were inspected.

\section{COSMOVISION AS A ROUTE TO SOVEREIGNTY}

In the years before the 2002 highway occupation, regionally based cultural activists had made considerable inroads into the cabildos of Caldono. One of the first was Luis Carlos Ulcué - originally from the tropical colonization zone of Caquetá, but whose parents were born in Caldono - who was elected to the governorship of Pueblo Nuevo in the late I990s. Luis Carlos came into conflict with its piously Catholic population when he advocated a return to reconstructed Nasa rituals intended to replace Christian practices. Since then, cultural activists and their allies have been elected to high posts in cabildos, to the zonal organization uniting Caldono's cabildos, and to CRIC's executive committee. The influence of cultural activists is evident in the councils' discourse, which revolves around cosmovision.

The councils united against the municipal mayor, pointedly affirming their ethnic ascendency and sovereignty by calling themselves the "indigenous communities of the ancestral territory of the Nasa People

I9. Autoridades Tradicionales del Territorio de Caldono, 2002. "Nuestra posición cultural y política: resolución de la Asamblea Permanente del Territorio Ancestral del Pueblo Nasa (Indígena) de Caldono”, Caldono, Cauca: mimeo. 
of Caldono" and by asserting that they "affirm[ed] and ratif[ied] the teachings of the elders about our Laws of Origin [and] the Greater Right [Derecho Mayor], founded in and lived through cosmovision". Here, for the first time in a public and intercultural space, a group of indigenous politicians was employing the discourse of cosmovision in its purest form - which is no accident, since the cabildo rosters included cultural activiststurned-local authorities.

In a widely circulated broadside, they argued, for example, that the Greater Right whose hegemony they sought, was a law originating at the center of the earth, and was meant for all people because all living beings were born from the Mother Earth. They asserted that their territory was at once cosmic and earthly, harmonized by rituals that ensured equilibrium among its inhabitants and ruled by the laws of the creator ancestors. They couched their demand for political autonomy in a discourse that combined the political language of self-determination with an acceptance of the role played by the spiritual world in orienting indigenous authorities. Their denunciation of the municipal mayor accused him of having violated ancestral law and of "trampling our dignity and integrity as Originary Peoples, charged with and pledged to the conservation and preservation of Harmonic Life in what we call planet Earth". Their condemnation was delivered "in the name of the Earth, the Sun, the Water, the Moon, and the cosmic, earthly, and subterranean spirits". The broadside was signed by the governors and captains of the six cabildos. Beside their signatures, the names of their offices were listed in both Nasa Yuwe and Spanish: the captains were called $s a^{\prime} t$ nebwe's $x$, combining the word for hereditary chief $\left(s a^{\prime} t\right)$ with that of legitimate authority (ne'bwe'sx), underlining the cosmic roots of their authority. ${ }^{20}$

While cosmovision has been a goal of the cultural activists who, for half a decade, have held cabildo office in the municipality, the culturalist approach had never before received the overwhelming reception that it did in 2002, when a critical mass of the Caldono indigenous community followed its traditional authorities into confrontation over the mayorality. The notion of the Greater Right that coalesced them was not, however, part of the local discourse; in fact, while the Guambianos have articulated this notion in their political demands for the past twenty-odd years, it had never before been expressed by CRIC-affiliated communities. The novelty of the discourse was, indeed, apparent in the speeches delivered at the gathering at La María. Most of the traditional authorities who spoke could say little about what constituted the Greater Right and they dwelled, instead, on how indigenous legislation - even the I99I constitution - was an imposition by outsiders.

Finally, for lack of material to cover, the organizers were forced to bring

20. Caldono, "Nuestra posición cultural y política”, pp. 2, 4 . 
in speakers from the outside, most notably, regional cultural activist, Inocencio Ramos, and - to my surprise - myself. Our presentations were preceded by a brief, very self-conscious, and abbreviated shamanic cleansing ceremony, consisting in chewing a small packet of herbs which, mixed with alcohol, was blown in the air, while two thê' walas mediated with the spirits; some participants criticized the ceremony as too public and inappropriate, given that it was conducted in broad daylight. I was first on the podium, taking the opportunity to speak about how Juan Tama the hereditary chief and founder of the resguardos of Caldono, who has become an icon of the Caucan indigenous movement - had laid the basis for the Greater Right. Inocencio took the Nasa translation of "constitution" - eç ne'bwe'sx or "the principal book" - and proceeded to explain why the Greater Right was more primordial than the constitution. The Greater Right could be translated as mantey neesnxi, which he cast in Spanish as an ancient ethical system that makes people nasnasa or "more Nasa". The staff of office carried by cabildo members, Inocencio pointed out, was inhabited by the guardian spirit, or $k s x a^{\prime} w$, thus transforming it into an object that embodies harmony and is emblematic of the cosmic roots of politics. He concluded that the language of the Greater Right is ritual in nature, aimed at redistributing energy to achieve equilibrium.

What was striking to me about this assembly was the tremendous discursive gulf that yawned between the indigenous politicians from other parts of Cauca and the Caldono-based cultural activists-cum-traditional authorities. The politicians spoke in the cadences of sovereignty, reiterating their support for Taita Floro and the need to build a coherent proposal for a new political system. The culturalists insisted upon the preeminence of cosmovision. Both are well-developed discourses of the indigenous movement, but their narrative tropes did not resonate with one another in this context. As a result, although the presentations persuasively synthesized the theoretical foundations of the Greater Right and the political conditions that had made its introduction necessary, no-one reached even the most preliminary of conclusions as to what implications this reasoning held for everyday political practice. It was as though two parallel intellectual and political projects, both springing from a single movement, had come into momentary contact to propel a community into action. The gulf between philosophy and practice was sensed by the representatives of other cabildos who had come to the assembly and who, in a debate mediated by CRIC officers, attempted to persuade Caldono to retreat from the radically indefensible position it had assumed.

\section{A CONFRONTATION WITH TAITA FLORO}

Taita Floro appeared at La María some six hours after the communities occupied the highway, accompanied by an entourage that included the 
then-Secretary of Government (a former member of the Quintín Lame Armed Movement, an indigenous guerrilla organization), representatives of the regional legal apparatus, and advisors. Unlike at earlier meetings in La María, where his electoral campaign hosted public events and where he was treated as an exemplary member of the indigenous community, now Taita Floro found himself representing the Colombian state, invited into the large open-air public meeting space to address the assembly and then banished to an out-building while the cabildos mulled over their response to him. Taita Floro told the Caldonos that they had placed him in an untenable position. As a former governor of Guambía, he intimated that he understood and fully supported their demand for recognition of their Greater Right as originary peoples - in fact, he asserted that, as a Guambiano, he knew more about the Greater Right than they did. But as governor of Cauca, he not only represented the indigenous communities that had propelled him into office, but also was the governor of the mestizo town-dwellers and peasants of Caldono, who for the most part, supported the municipal mayor and feared the asendancy of the cabildos.

Taita Floro's quandary is underlined by Ernesto Laclau in his explication of the dynamics of the coalition politics of new social movements. ${ }^{21}$ Laclau reasons that the organization that assumes the leadership of a coalition is forced to place its own demands on the back burner in the interests of representing a communal platform. In the process, its organizational dynamic is muted and weakened. But the longterm unity of the coalition is also placed in danger, because its survival is premised on the vitality of the component organizations and, in particular, of the coalition leadership. Were Taita Floro to take up the Greater Right as his banner - which is precisely what Guambiano cabildo governors do he would risk alienating the mestizo members of the coalition that elected him. When he showed reluctance to engage the cabildos of Caldono to the exclusion of his peasant constituency, he was seen by the Caldonos as a sell-out. The movement's very objective of refashioning the state, then, requires that the indigenous agenda must, necessarily, fall by the wayside.

But it is not only the exigencies of the coalition that forced Taita Floro to take the position he did - so did the requirements of the Colombian state. As he explained to the assembly, his options were limited by the office he held. A cabildo governor simultaneously fills executive, judicial, and legislative functions, Taita Floro told the congregation, but the governor of Cauca does not - cannot - encroach upon the prerogatives of other branches of government. He could not force Iván Sandoval to resign, but was obliged to let accepted legal procedures take their course. What went unaddressed was the intense political pressure being exerted by Taita Floro's political opponents among the regional mestizo elite, who had lost

21. Ernesto Laclau, Emancipations (London, 1996), ch. 3. 
the governorship to the popular coalition and eagerly awaited his downfall as a result of the confrontation with Caldono. ${ }^{22}$ This was what most concerned many influential colaboradores, who immediately deployed respected public figures to evaluate the legality of the Caldonos' demands and defuse the situation.

In short, Taita Floro was about to become a casualty of the contradictions between community and state that indigenous politicians are discovering as they assume public office. He was from the community, but no longer of it. ${ }^{23}$ At stake was his own political future in the eyes of his indigenous and mestizo constituents and the broader Caucan society. At stake, also, was the legitimacy of the indigenous movement as the vanguard of a broader popular coalition, as well as the extent to which its paired discourses of sovereignty and culture were at all relevant to other coalition members.

Ultimately, Taita Floro achieved a middle road: he persuaded the Caldonos to open the Pan-American Highway to traffic and assembled a commission to work with them at laying the groundwork for future legislation to establish "indigenous territorial entities", the geo-administrative units of the Colombian state governed by indigenous people that are proposed in the 1991 constitution, but have never been legislated into existence by a recalcitrant Congress. ${ }^{24}$ The cabildos of Caldono are now engaged in that process, attempting to harness the discourses of cosmovision and sovereignty into a new politics of indigenous citizenship. Thus, the 2002 confrontation at La María did not end in failure for any of the parties involved. Taita Floro effectively defused a dangerous conflict, the regional culturalist intellectuals ensconced in local councils were provided with a space in which to ground their utopias in political practice, and even the municipal mayor and his supporters were given a temporary lease on life (at least, until the ponderous state bureaucracy makes public its decision on his continued tenure).

\section{CONCLUSION}

While the Gramscian model helps us to conceptualize the differences between the articulation of intellectuals with social movements and the mediating function that Latin American intellectuals have filled between civil society and the state, we need to go beyond it to make sense of how intellectuals impact upon the face of indigenous politics. That is, we must

22. El Liberal (Popayán), 25 July 2002, p. I, and 26 July 2002, p. I.

23. I am indebted to Arquimedes Vitonás, a Nasa anthropology student and currently the municipal mayor of Toribío, for clarifying this concept for me.

24. Enrique Sánchez, Roque Roldán, and María Fernanda, Derechos e identidad: los pueblos indígenas y negros en la Constitución Política de Colombia de I99I (Bogotá, I993). 
inquire into how the very heterogeneity of the movement is itself a fertile ground for the construction of a native political ideology. What I am proposing contrasts with existing work on Latin American indigenous movements. Scholars generally tend to describe these organizations as homogeneous with generic "indigenous" memberships. As a consequence of our inattention to the complexity of the membership of these organizations and the multiple discourses engendered by them, however, we frequently come up short. We deny ourselves the conceptual space needed to interpret the relationship between the internal multiculturalism of these organizations and the pluralist demands that they project to the dominant society. Instead, we have persisted in essentializing them, producing the image of a package of separatist demands lodged in the nostalgic appeal to a primordial culture, which in no way reflects their intellectual dynamism or the protagonist role that they are playing throughout the continent.

The creation of a typology of intellectuals organic to the indigenous movement, which is what I did in the first half of this article, only takes us so far. In order to comprehend how an organizational voice emerges, we must conceptualize the different discourses of the various sectors within the movement, and we must study how they are engaged in the course of negotiations both internal and external to the movement. For me, one of the most useful tools for arriving at this conceptualization is the distinction between culturalist projects and discourses of sovereignty, between an inward-looking emphasis on the revitalization of cultural specificity and an emphasis on universal languages of minority rights that discursively and practically links the indigenous movement to other progressive social sectors and makes possible negotiation with the state. As Bruce Albert so cogently argues in his interpretation of the discourse of Davi Kopenawa, a Brazilian Yanomami leader, the only way that the indigenous movement can hold its own in an ethnically heterogeneous political field is if it looks simultaneously toward political universals and cultural specifics. ${ }^{25}$

It is at the intersection of these two discourses that the articulation of the cultural project with the movement's political objectives can be most fruitfully explored. This calls for a comparative analysis of the positioning of indigenous intellectuals in local and regional venues, as well as an understanding of the fluidity of their discursive practices within the diverse political contexts in which they operate. Accordingly, we must explore the alliances, dialogues, and disjunctures among the indigenous

25. Bruce Albert, "O ouro canibal e a queda do céu: uma crítica xamânica da economia política da naturaleza" (Brasilia: Série Antropologica no. 174, Departamento de Antropología, Universidade de Brasília, I995), p. 4. See also Allen Chadwick, Blood Narrative: Indigenous Identity in American Indian and Maori Literary and Activist Texts (Durham, 2002); Les Field, "Complicities and Collaborations: Anthropologists and the 'Unacknowledged Tribes' of California”, Current Anthropology, 40 (1999), pp. 193-209. 
cultural activists who move in the regional sphere, regional and local indigenous politicians, colaboradores, local native intellectuals, and shamans. While their ultimate aim is to construct a movement that speaks to the dominant society in what appears in the course of mobilizations as a single voice, their objectives emerge out of the heterogeneity of their agendas, their methodologies, and their discourses.

It is through the confrontation of discourses of diverse intellectuals politicians, cultural activists, shamans, colaboradores - that a communal voice is achieved in the Colombian indigenous movement. The mediating function that they fill between community and national society, or between indigenous movement and the state, is made infinitely complex by the heterogeneity within their ranks. If we are to comprehend the discourse of indigenous movements, then, we must pay heed to this heterogeneity, recognizing it as the ground upon which politics is constructed. 